た。したがつて, シメトリンを移植栽培に利用する場 合, とくに砂質土壤で薬害の危険性が大きいと考学られ るが，漏水条件を加えて土壤と薬害との関係をさらに検 討する必要がある。

\section{引用 文 献}

1）荒井正雄・古谷勝司・宮原益次： $s$-トリアジン系除草剂の作用性に 関する研究 第 1 報 水稲・タイヌビエの発芽時地下部処理に打什 る殺草性の $s$-トリアジン誘導体間差異について. 日作紀 36（3), 310 314 (1967).

2）荒井正雄・古谷勝司： $s$ ートリアジン系除草剤の作用性に関する研究 第 2 報 メチルメルカプト誘導体の水稻・タイヌビエに対する殺草
性の温度による変動について。日作紀 36（3），315～319 (1967).

3) 伊藤憲作・阿部靖典・鈴木 保：日本雑草防除研究会第 7 回講演会 要旨 (1968).

4) HARRIS, C.I. and T.J.ShEETS : Influence of soil properties on adsorption and phytotoxicity of CIPC, Diuron, and Simazine. Weeds 13 ( 3 ), 215 218 (1965).

5) LAMBERT, S.M. : The influence of soil-moisture content on herbicidal response. Weeds 14 ( 3 ), 273 275 (1966).

6) 日本植物調節郕研究協会：昭和 42 年度夏作関係除草剂適用性判定 試験成績総合要録 (水稲編).

7）野田健児・茨木和典：除草刘，主として prometryne の作用力 の温度による变動要因の一考察. 雑草研究 7, 105 110 (1968).

8) Talbert, R.E. and O.H.Fletchall: The Adsorption of some $s$-triazines in soils. Weeds 13 (1), 46 52 (1965).

\title{
Factors Affecting the Injury of Simetryne to Rice Plants
}

\author{
Shooji Furuya and Takayoshi Kataoka \\ Central Agricultural Experiment Station, Konosu, Saitama
}

\section{Summary}

We examined to clarify the factors affecting the injury of 4,6-bis (ethylamino)-2-methylthio-1, 3, 5triazine (simetryne) to rice plants. The results were as follows :

1) In the soil-incorporated treatment of simetryne with non-flooded conditions, the injury on the germinating rice plants was much great in higher soil moisture and in higher temperature. Although the injury was greater in the coarse sandy loam than in the light clay, the difference was slight.

2) In the soil-incorporated treatment with flooded conditions, the injury on the early-staged rice plants was remarkably greater in the coarse sandy loam than in the light clay.

3) In the case of application on the soil surface under water, the injury on the early-staged rice plants was greater in the shallowly-flooded $(1 \mathrm{~cm})$ than in the deeply-flooded $(4 \mathrm{~cm})$, while the difference in the injury among three temperatures was not great.

\section{水田水稲作における P C P の施用法と流亡, 消失}

\section{農林省九州農業試験場 江口未馬・野田健児}

\section{は じめに}

水田に使用された除草剂 PCP が散布直後の集中的な 豪雨によつて，河川や海水に流入し，それが魚貝類に影 響するとされ，1961，1962 年に暖地に打いて特に問題 となつた。当時魚毒性軽減のための基礎的知見をえんと して，PCP とその 2,3 の混合肥料除草剂について，施 用方法と施用時期によつて, 土壤への吸着がぞのように
違い, 消失の過程にどのような差があるかを知り, 流出 の危険度を推定すると共に，施用法による除草効果の羑 についても明らかにする目的で試験を行なつた。

すでに，魚毒性の問題は低毒性除草剤の開発によつて 解決されたが，未だ PCP 粒剤の実際使用はわが国除草 剂中第 1 位であり, PCP 使用未制限地帯での 魚毒軽減 のための一つの技術的素材を提供するものと考光, 結果 の概要を報告するものである。 
この種の報告については, 能勢ら $ら^{4,5,6,7,8,9,10,11)}$ の土壌 物理，化学的な面からの報告があるが，筆者らは実際の 固場条件下に批汀る, PCP の分布, 除草効果, 稲に及汪 す影響なぞについて述べてみたい。

\section{試 験 方 法}

供試除草剤及び薬量：PCP 粒剤 $25 \%, \mathrm{PCP}$ 化成 $[(\mathrm{N})$ 14\% · (P) 14\% ( $\mathrm{K}) 10 \% \cdot(\mathrm{PCP}) 4 \%], \mathrm{PCP}$ 尿素 [(N) $41 \% \cdot(\mathrm{PCP}) 7 \%$ ] の 3 薬剂, いずれも施用量は $\mathrm{PCP}$ $100 \mathrm{~g} / \mathrm{a}$ (成分)。肥料要素については, 単肥によつて等量 に補正した。

試験区の設定：(1) 荒代前 (入水前) 施用区一耕起後, 入水前に全面散布し，レーキにて約 $5 \mathrm{~cm}$ 層にかくはん。 (2) 植代前 (入水後) 施用区一入水乙荒代後全面散布し, 植代によつて, かくはん。(3) 田植後表層施用区一田植 活着後, 表層に全面散布。な称標準区は, 荒代前区は乾 田状態で，植代前区及び田植後区は湛水状態で施肥する ため肥効が異なると推定されたので，荒代前区と植代前 区及び田植後区の各々について設けた。

試験区を一括表示すると第 1 表のとおりであり，また 土壤条件については第 2 表に示した。

第 1 表 試 験 区 $の$ 説 明

\begin{tabular}{|c|c|c|c|c|c|c|c|c|c|}
\hline & \multirow{2}{*}{ 区 } & \multicolumn{5}{|c|}{ 月 } & \multicolumn{3}{|l|}{ 日 } \\
\hline & & 7.22 & 23 & 24 & 25 & 26 & 27 & 28 & $2^{0}$ \\
\hline 荒代前区 & $\begin{cases}P C P & \text { 粒剤 } \\
P C P & \text { 化成 } \\
P C C P & \text { 㽷素 } \\
\text { 標 } & \text { 準 }\end{cases}$ & 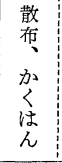 & $\begin{array}{l}\text { 入 } \\
\text { 水 } \\
\text { 植 } \\
\text { 代 }\end{array}$ & 田 & & & & & \\
\hline 植代前区 & $\begin{cases}P C P & \text { 粒剂 } \\
P C P & \text { 化成 } \\
P C P & \text { 氺素 }\end{cases}$ & 水 & $\begin{array}{l}\text { 散 } \\
\text { 布 } \\
\text { 植 } \\
\text { 代 } \\
\end{array}$ & $\begin{array}{l}\text { 田 } \\
\text { 植 } \\
\end{array}$ & & & & & \\
\hline 田植後区 & $\begin{cases}\mathrm{PCP} & \text { 粒郕 } \\
\mathrm{PCP} & \text { 化成 } \\
\mathrm{PC} \mathrm{P} & \text { 㽷素 } \\
\text { 標 } & \text { 菹 }\end{cases}$ & 入 & 植 & 田 & & & & & 散 \\
\hline
\end{tabular}

第 2 表 土 諘 条 件

\begin{tabular}{|c|c|c|c|c|c|}
\hline $\begin{array}{l}\text { 質 } \\
\text { 性 }\end{array}$ & 腐 植 & $\mathrm{pH}$ & $\begin{array}{l}\text { 塩基置換 } \\
\text { 量 }\end{array}$ & $\begin{array}{l}\text { 最 } \\
\text { 水 } \\
\text { 容 } \\
\text { 量 }\end{array}$ & 減 水 深 \\
\hline 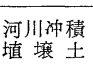 & $3.41^{\%}$ & $\begin{array}{l}5.7 \quad \text { (水) } \\
4.4(\mathrm{~N}, \mathrm{KCl})\end{array}$ & $\begin{array}{l}\mathrm{me} / 100 \mathrm{~g} \\
22.08\end{array}$ & $70 \sim 73^{\%}$ & $4 \sim 6 \mathrm{~cm} /$ 日* $^{*}$ \\
\hline
\end{tabular}

注） * 水田化して年次が浅いため減水深が大きい。

試料の採取：直径 $15 \mathrm{~cm}$ のビニール製円筒を打ち込 み, その円筒中の水を減圧びんで吸引採取し, 水の分析 材料とした。水の採取後土壤表面が露出した時, 円筒中 に core samplerを打ち込み土壤を採取して，これをそ のまま冷蔵庫内 $\left(2 \sim 3^{\circ} \mathrm{C}\right)$ に一夜保存して翌日 $1 \mathrm{~cm}$ 毎
に分離し，層位分布の測定材料とした。層位分布につい ては, 各区の散布当日（ 6 時間経過後）と翌日（24 時間 経過後）の 2 回（但し荒代前区は入水後 6,24 時間後） について採取測定した。経時的変化については，当日， 翌日の值は層位分布の $1,2 \mathrm{~cm}$ 層の測定値の平均值を とり，以後については表層 $2 \mathrm{~cm}$ を採取し，十分にかく はんしたものについて測定した。

分析方法 : 水は遠心沈澱機（3,000回転/分，10分間） により清澄にし，キシンン抽出を行なつた。抽出操作は 初期の高濃度試料については $50 \mathrm{cc}$, 以後時日の経過に 従い 200 500cc について, 往復式の振盪器によつて 5 分間行なつた。

土壌は $20 \mathrm{~g}$ を科取し, 塩酸 $10 \mathrm{cc}$ を加えて, 水蒸気蒸 留し, 約 500cc の留液を得るまで蒸留をつづけ, この留 液 $100 \mathrm{cc}$ についてキシレン抽出操作を行なつた。但し低 濃度試料については留液 $200 \mathrm{cc}$ を操作した。操作は水の 昜合と同様に往復式の振盪器で 3 分間振盪抽出した。定 量は 4-アミノアンチピリン比色法5)に従つた。但し 4アミノアンチピリン水溶液は $0.2 \%$ 液, $2 \mathrm{~m} l$ を加えた。

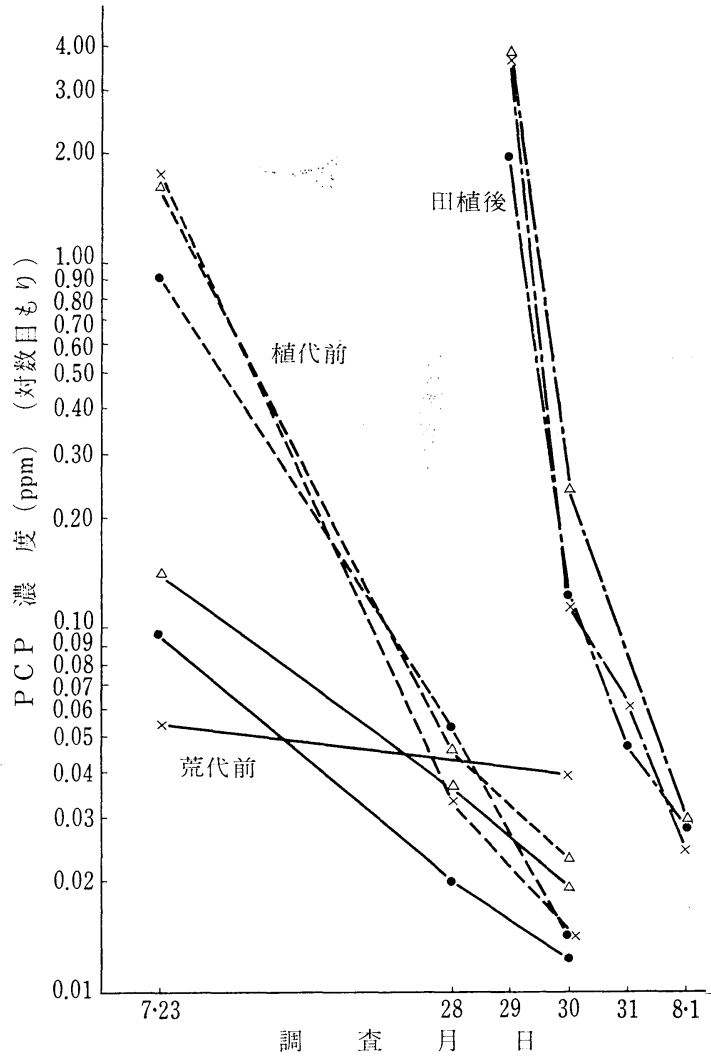

第 1 図 水中の $\mathrm{PCP}$ 濃度变化

注）・：PCP 粒剤, $x: P C P$ 化成, $\triangle: P C P$ 尿素 


\section{結果 及び考察}

\section{（1） 水中の PCP 濃度}

荒代前区は入水前に散布かくはんし，翌日 までそのまま放置したため，すでに土壤への 吸着が大きく, 入水後の溶出量は極めて少な く, 水中濃度は他の 2 区に比べて著しく低 心。植代前区は散布後 6 時間では $1.0 \sim 1.7$ ppm であるが， 5 日後では約 $1 / 30$ の濃度と なり，急速な低下を示す。田植後区の場合 恃, 表層施用で無かくはんのため, 散布 6 時 間後の濃度は 3 区中最も高く, $3.0 \sim 4.0 \mathrm{ppm}$ であるが， 3 日後では約 $0.03 \mathrm{ppm}$ となり， その濃度は極めて急激に低下する。このよう 、田植後区の濃度低下が著しいことは，混層 されないため土壤吸着が招そく，流亡水によ る消失が相対的に大きかつたこと辛，また表 層施用のため日光による分解も大きかつたこ となどが考えられる。

その後は，いずれの区も灌溉水を導入して 汐水中の PCP 濃度の高まりはみられない。 すなわち，一旦吸着された PCP の溶出は， 本試験の供試围場のよらな土壤では比較的少


潵布直後の未吸着のものの量によつて支配さ れることが大と考兄られる。

除草剂の種類による水中濃度の本質的な美 はみとめられない(第1図参照)。

\section{(2) 土壤中の PCP 濃度}

a) 層位別分布 荒代前区の場合は，入水 前乾田状態に执いて散布かくはんしたため, よく土壤中に混入され, 比較的下層まで分布 している。層位別にみると，2 3cm 層が最高濃度を示 し，表層部の濃度が低い。これは，この区が一日間無湛 水の状態で日光にさらされたため分解されたものと考兄 られる。植代前区の場合は, かくはんの効果が無湛水下 (荒代前区)で行なわれたほどはみとめられない。すな わち，濃度は表層部が極めて高く，下層になるにしたが 心急激に減少する。さらに，田植後区の場合は，無かく はん表層散布のため, 表層に吸着されたものが相対的に 多く, 散布後 6 時間では下層への移動は汪とんどみとめ られないが，翌日にはやや下層への分布がみられる。ほ とんぞ表層にのみ吸着されたにもかかわらず，その濃度 蚮他の 2 区に比べて低い。このことは, 散布後 6 時間に 排ける水中濃度の高いことから考えると, 土壤吸着が十



第 2 図土壤中の $\mathrm{PCP}$ 濃度（層位分布）

1) - : PCP 粒刜 (a), $x: P C P$ 化成 (b), $\triangle: P C P$ 尿素 (c)

2) 左側 : 6 時間後, 右側 : 24 時間後

分に行なわれないらちに，減水深の大なることによつて 急速に流亡したものがあつたためと推察される。除草剤 間ではその分布について，特に異なる点はみとめられな い(第 2 図参照)。

b) 経時的変化 一旦土壤に吸着された PCP の消失 は，極めて徐々に行なわれる。第 3 図に示すように，荒 代前区の場合は散布後 10 日目に打いてもかなりの高濃 度を維持しており，減少の曲線は緩慢である。植代前区 の場合も荒代前区とほとんど同様の傾向を示すが，最初 の濃度の高い PCP 粒剤, PCP 尿素の減少がやや大きい ように思われる。すなわち，高濃度からある一定の濃度 飞達するまでの消失は急速であるが，それ以下への消失 は比較的緩慢になるものと推察される。田植後散布区の 



第 3 図土壤中の PCP 濃度变化

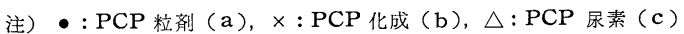

場合でも，濃度そのものも低いが前 2 者と同様に緩慢な 減少傾向をたどる。

経時的変化についても, 除草剤間に異なる点は特には

みとめられない。



第 4 図除草効果及び収量の比較

注) $\mathrm{a}: \mathrm{PCP}$ 粒剂, b : PCP 化成, c : PCP 尿素

\section{(3) 除草効果}

時期がおくれたため雑草の発生量が少なく，しかも区 による変動が若干みられたが，一応の結果について述べ ると，植代前区と荒代前区では，ほとんど同程度の効果 を示し, 田植後散布区ではやや劣る傾向がみられた。こ のことは，この区が無かくはんのため土壤吸着が少な く，しかも減水深が大きいため未吸着の PCP の流亡が 相対的に大きかつたことに原因するものと考学られる (第 4 図参照)。

\section{（4）生育及び収量}

荒代前区では田植後若干の下葉枯れがみられ，したが つて初期の茎数はやや減少の傾向にあつた。しかし収量 については全く影響はみられない。植代前区では散布 2 〜 3 日後に调萎現象がみられ，一部個体には下葉枯れが 発生した。生育中の茎数では標準と大差なかつたが，収 量では若干減収となつた。拈そらく混層かくはんされて 下層分布した PCP が，根の発育に対する抑制など2) 後

第3表 気 象 条 件



注）九農試, 農業気象研究室測定 
期まで影響したものと考えられる。田植後区では散布後 葉身が褐変し，ついで下葉枯れがみられ，いずれの除草 剂区に拈いても若干の欠株を生じた。これは散布直後の 水中の高濃度と高温（第 3 表）に原因する接触的な障害 と考兄られるしかし全般に回復が早く，欠株による減 収程度にとどまつた。したがつて適正条件下で散布され た場合には，田植後区が植代前区より薬害，及びその回 復の点で, より好ましいと考兄られる（第 4 図参照）。

\section{む す び}

以上の試験結果から，PCP 粒剂，及び PCP を含む混 合肥料除草剂は, 荒代前または植代前に混層処理するこ とが，田植後表層施用に比べて，その流亡，消失は少な い。土壤中の分布は，乾田状態に打いて混層かくはんす る方が湛水状態において混層かくはんするよりも，より 下層まで分散する。表層施用は土壤吸着が少なく，初期 水中濃度が高い。したがつて散布直後の豪雨などの場合 は, 表層施用の方が混層施用よりも多くの PCP が流出 するものと考えられる。

除草効果については処理区間に本質的な差はみられな かつたが，稲の生育収量の点からみれば荒代前区が最も
まさつた。植代前区と田植後区とでは，薬害及び回復性 の点からは田植後区の方がまさる傾向がみられる。なお 除草効果, 稲の生育収量については, 除草剤間に判然と した差はみとめられなかつた。

PCP の流出，流亡については，量的には混層するこ とにより一時的に多量に流出することを防止することは できるが，稲に対する影響の点から考えると，田植前の 混層処理が田植後処理に比べて果たして安全, 確実な技 術であるかどらかは, 栽培的, 土壌的, 地域的な条件に よつて相違するので，その点を十分考慮しなければなら ない。

\section{引用 文 献}

1）麻生末雄・阪本 健 : 土肥誌 34, 164 168 (1963).

2) 橋本雄司・凨田秀男: 土肥誌 35, 90 94 (1964).

3）九州農業試験場環境第二部：土㙵中に打ける PCP-Na の行動に関 する試験. プリント 昭和 39 年 12 月.

4) 能勢和夫・福永一夫 : 農薬生産技術 No. 6, 27～38 (1962).

5）能势和夫・福永一夫 : 農薬生産技術 No. 9, 31 34 (1963).

6）能势和夫・鈴木隆之・福永一夫 : 土肥誌 34, 243 246 (1963).

7) 能势和夫・鈴木隆之・福永一夫 : 土肥誌 34, 291 295 (1963).

8）能勢和夫・鈴木隆之・福永一夫 : 土肥誌 34, 367 370 (1963).

9）能勢和夫：土肥誌 35,228 (1964).

10) 能勢和夫 : 土肥誌 35,306 (1964).

11）能勢和夫：農技研報告 C No. 20, 225 277 (1966).

\title{
Application Methods of PCP Granule and Its Fate in Water and Soil on Paddy Ricefields
}

\author{
Suema EGUCHI and Kenji NodA \\ Kyushu Agricultural Experiment Station, Chikugo, Fukuoka
}

\section{Summary}

In order to obtain basic information for creating the way of alleviating the toxicity of PCP granule to fish and shell-fish, we have performed the investigation about distribution and persistence of PCP granule in water and soil in cases of some different application methods on transplanted rice paddy fields in 1964.

PCP granule incorporated into soil before transplanting of rice seedlings remained longer and more deeply distributed in soil than one applied on the surface of soil after transplanting. This tells us that the incorporation method should be more effective in protecting fish and shell-fish from toxicity that may occur owing to a heavy rainfall.

On the other hand, effect of weeding was found to be highest in a case where PCP was incorporated into soil at the time of rough-puddling before transplanting, but the damage of rice seedlings and their recovery was found to be lighter and faster, respectively, in a case of surface application after transplanting, than in other methods.

Generally speaking, the most suitable application method of PCP granule or PCP and fertilizer mixtures should be taken into consideration from two points of veiw; first, security to fish and shellfish and, secondly, effectiveness as a herbicide. 